http://kitaibelia.unideb.hu/

ISSN 2064-4507 (Online) • ISSN 1219-9672 (Print)

(C) Department of Botany, University of Debrecen, Hungary

23 (1): 77-86.; 2018

DOI: $10.17542 /$ kit.23.77

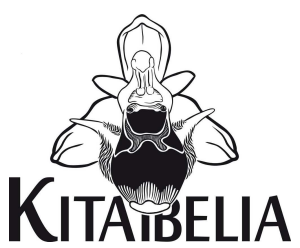

\title{
A ruházat szerepe az ember általi magterjesztésben
}

\author{
LUKÁCS Katalin ${ }^{1} \&$ VALKó Orsolya ${ }^{2}$
}

1Debreceni Egyetem TTK Ökológiai Tanszék, H-4032 Debrecen, Egyetem tér 1.

2MTA-DE Biodiverzitás Kutatócsoport, H-4032 Debrecen, Egyetem tér 1.; valkoorsi@gmail.com

\section{The role of clothing in antropochorous seed dispersal}

\begin{abstract}
Humans play an increasing role in seed dispersal. Through human help, seeds can bridge distances which otherwise would not be possible. The most important human-mediated dispersal types are: the spread on clothing, shoes and vehicles. The effect of these dispersal types can be combined in many cases. During dispersal with clothing, the seeds attach to cloths, but its probability depends on whether the seeds or other parts of the plant have morphological characteristics which make the attachment possible (e.g. hooks, hairs, spikes) and on the adhesion characteristics of the clothing (cotton/nylon, drill/cotton). This way, cloth-dispersal can be considered analogous to epizoochory. In our review, we evaluated the publications about human-mediated seed dispersal on cloths. In total we have found twelve experimental and field studies on the topic. So far, seeds of 449 species have been documented to be able to spread on clothing worldwide, out of the 449 species, 262 occur in Hungary. With future studies, these numbers will be increasing considerably. The average dispersal distance of the seeds was estimated between 150 and $5000 \mathrm{~m}$, but the distance could be significantly increased, if means of transport are used during the dispersion. According to the results, the seeds of weed and invasive plants are dispersed most frequently on clothing ( $87 \%$ of all species, $26 \%$ of species occurring in Hungary). These cause serious damage worldwide. We emphasise that people should pay attention to the type of clothing, when they are visiting remote and unique nature reserves. For instance, waterrepellent foot wears could significantly reduce the adhesion of the seeds therefore it can prevent unintended seed dispersal. Further investigations are needed to find solutions to these problems, especially in regions with lack of these studies, such as in Europe, South America, Asia and Africa.
\end{abstract}

Keywords: hemerochory, human-mediated dispersal, clothing, adhesion

Összefoglalás - A növények terjedésében egyre nagyobb szerepet játszik az ember. Emberi segítséggel olyan távolságokra is képesek eljutni a magvak, ami másképp nem volna lehetséges. A legfontosabb ember általi terjesztés típusok: a ruha, a cipő és a járművek közvetítésével történő terjedés. Ezen típusok hatása sok esetben együttesen is érvényesülhet. A ruházattal történő terjesztés során a diaspórák a ruházatra tapadnak, viszont ez fóként akkor valósulhat meg, ha a magok vagy a növény egyéb részei rendelkeznek a tapadáshoz szükséges morfológiai jellegekkel (pl. horgok, szőrök, pappuszok) és a ruházat anyaga is lehetővé teszi a tapadást (pamut/nylon, vászon/pamut). Ebből kifolyólag az ember is képes lehet az állatokhoz hasonlóan magokat terjeszteni a tájban. Mindezidáig kevés vizsgálatot végeztek ebben a témakörben, ezért tanulmányunkban összegyüjtöttük azokat a kutatásokat, amelyek az emberi ruházaton történő magterjedéssel foglalkoztak. Összesen tizenkét kísérletes és terepi kutatást találtunk, melyek módszereit és eredményeit részletesen megvizsgáltuk. Az eddigi vizsgálatok alapján összesen 449 faj esetében mutatták ki a ruházaton való terjedés képességét, ezek közül 262 Magyarországon is előfordul. A magok átlagos terjedési távolsága 150 és 5000 m közötti volt, de a távolság jelentősen nőhet, ha a terjesztés során közlekedési eszközt is használunk. Az eredmények alapján a ruházattal többnyire a gyom- és inváziós növények propagulumai terjednek (az összes faj 87\%-a, a Magyarországon is előforduló fajok 26\%-a), amelyek súlyos károkat okoznak világszerte. Erre a problémára megoldás lehetne, ha a kiemelten értékes természetvédelmi területek látogatásakor az emberek odafigyelnének a kiválasztott 
ruházat típusára, ugyanis a vízlepergető lábszárvédők használata lényegesen csökkenteni tudja a magok tapadását és megelőzné a természetvédelmi szempontból nem kívánatos fajok terjesztését. További kutatásokra van szükség, hogy megoldásokat találjunk ezekre a problémákra, különösen azokban a régiókban, ahol korlátozott a kutatások száma ebben a témakörben, mint Európa, Dél-Amerika, Ázsia és Afrika.

Kulcsszavak: ember általi magterjesztés, magmorfológia, ruházat, tapadás

\section{Bevezetés}

A magterjesztő vektoroknak kiemelkedő szerepük van a növények terjesztésében és az új élőhelyek benépesítésében. Az abiotikus és biotikus vektoroknak köszönhetően a magok hatékonyan terjedhetnek a szél (anemochoria), a víz (hidrochoria) és az állatok (zoochoria) segítségével (LEVIN et al. 2003). Ahogy az állatok, sokszor az ember is képes akaratlanul diaspórákat szállítani egyik élőhelyről a másikra (VITOUSEK et al. 1997, KuLBABA et al. 2009). Az ember általi magterjesztésnek ma már számos formáját ismerjük. Ezek közül a járművek a távolsági terjesztés leghatékonyabb vektorai (TAYLOR et al. 2012). Segítségükkel az ember óriási távolságokat képes megtenni, ezáltal pedig növelni tudja a magvak térbeli szétszóródásának lehetőségeit (PICKERING \& MOUNT 2010). A járművek mellett az emberi ruházat is fontos szerepet tölt be a propagulumok terjesztésében. Akár szabadidős tevékenységekről legyen szó, akár természetben végzett munkáról, az ember a cipőjén és a ruházatán egyaránt terjesztheti a magokat (HARDIMAN et al. 2017).

Ahhoz, hogy a diaspórák hatékonyan terjedhessenek a ruházaton, számos feltételnek kell teljesülnie. A magvak sikeresebben tapadnak a ruházathoz, ha rendelkeznek a tapadáshoz szükséges morfológiai jellegekkel, mint például hosszú szőrökkel, horgokkal (MounT \& PICKERING 2009, AUFFRET \& Cousins 2013). Az emberi viselkedés is nagymértékben befolyásolhatja a magvak ruhára való tapadását, mivel függ a viselt ruházat típusától, a viselkedési formától és a megtett távolságtól (MounT \& PICKERING 2009, ANSONG et al. 2015). Sok esetben az időjárási viszonyok is hatással lehetnek a tapadásra, azáltal, hogy elősegítik azt (pl. szél, sár), vagy épp megakadályozzák (pl. eső) (WichmANN et al. 2009).

Az ember általi magterjesztéssel kapcsolatos vizsgálatok alapján az ember leginkább a gyomnövények magjainak terjedését segíti világszerte (HUGHES et al. 2010, PICKERING \& MOUNT 2010). Ez aggodalomra ad okot, mivel a gyomok terjedése veszélybe sodorja a ritka, védett, endemikus és őshonos fajokat, különösen az olyan elszigetelt és sérülékeny területeken, mint például Ausztrália, vagy az Antarktisz (ANSONG \& PICKERING 2014, HuISKES et al. 2014). Ugyanakkor az ember általi magterjesztés lehetőséget nyújthat azon növényfajok számára, amelyek fragmentált élőhelyekre kényszerültek és a tájban az egykor jellemző terjesztő vektorok, mint a legelő állatok, visszaszorultak. Az élőhelyek fragmentációja és izolációja miatt napjainkban a táj egyre kevésbé átjárható (NIGGEMANN et al. 2009), mind az állatok, mind a növényfajok számára (NATHAN 2006, AUFFRET 2011, DEÁK et al. 2016a). Ezért azon növényfajok magjai, amelyek képesek az ember által is terjedni sikeresebbek lehetnek az új területek kolonizálásában (AUFFRET 2011). A fragmentált tájban nem csak az ember, hanem a fragmentációra kevésbé érzékeny állatfajok, így a madarak magterjesztő szerepe is megnőtt (VAN DER PIJL 1982, ANDERSON et al. 2015, LOVAS-KISS et al. 2015, LOVAS-KISS et al. 2018).

PICKERING \& MOUNT (2010) felméréséből kiderült, hogy világméretű áttekintésben a legtöbb ember által terjesztett növényfaj Európában őshonos, amely komoly problémákat okoz a többi kontinensen. AUFFRET (2011) Svédországban végzett kutatása pedig azt a lehetőséget vizsgálta, hogy Európában pozitív hatásként jelentkezhet az ember általi magterjesztés a fragmentált területeken. Ahhoz, hogy jobban megérthessük az ember szerepét a magok terjesztésében, kiterjedt vizsgálatokra van szükség minden ember általi magterjesztési típusra vonatkozóan. Mivel az embernek komplex szerepe van a magterjesztésben, tanulmányunkban, azokat a kutatásokat gyűjtöttük össze, amelyek az ember ruházatán terjedő magok vizsgálatával foglalkoznak. 


\section{Anyag és módszer}

2018 januárjában a Google Scholar adatbázis segítségével gyűjtöttük össze azokat az angol nyelven publikált kutatásokat, amelyek a ruházaton terjedő magok vizsgálatával foglalkoznak. A következő kulcsszavakat használtuk a kereséshez: “human-mediated dispersal”, „seed dispersal” és „cloth*”. Összesen 615 találatot eredményezett a keresés (2018. január 17.). A kapott cikkek címeit és kivonatait átnézve mindössze huszonkét kutatás említette legalább érintőlegesen a magok ruházattal történő terjedését. A vizsgált publikációk irodalomjegyzékéből tovább bővítettük a listát, azokkal a cikkekkel, amelyek szintén az ember általi magterjesztéssel foglalkoztak.

A cikkek részletes áttekintése után összesen tizenkét olyan kísérletes vizsgálatot találtunk, ami a ruhán való magterjedéssel foglalkozik. Vizsgálatunkban arra voltunk kíváncsiak, hogy milyen módszereket alkalmaztak a kutatók a magok ruhán keresztüli terjedésének a tesztelésére.

\section{Eredmények és értékelésük}

A ruházattal történő magterjesztéssel kapcsolatban mindössze tizenkét kísérletes és terepi vizsgálatot találtunk (1. táblázat), amelyek eredményei jelen tanulmányban rövid bemutatásra kerülnek.

1. táblázat. Az emberi ruházaton terjedő magokkal végzett kutatások hivatkozásai, régiók, élőhelyek, módszerek és a kutatás során azonosított fajok száma és az adott régióban betöltött ökológiai szerepe (az adott tanulmány szerzőinek besorolása alapján)

Table 1. References to research on seed dispersal on human clothing, regions, habitats, methods and the number and ecological role of species identified during research

\begin{tabular}{|c|c|c|c|c|}
\hline Hivatkozás & Régió & Élőhely & Módszer & $\begin{array}{c}\text { Azonosított } \\
\text { fajok }\end{array}$ \\
\hline $\begin{array}{l}\text { ANSONG \& } \\
\text { PICKERING } 2013 a\end{array}$ & Ausztrália & Kakadu Nemzeti Park & terepi kísérlet & 1 (gyepi) \\
\hline $\begin{array}{l}\text { ANSONG \& } \\
\text { PICKERING } 2013 b\end{array}$ & Ausztrália & $\begin{array}{l}\text { D’Aguilar Nemzeti } \\
\text { Park }\end{array}$ & kérdőíves felmérés & gyom és inváziós \\
\hline ANSONG et al. 2015 & Ausztrália & $\begin{array}{l}\text { Gold Coast Campus, } \\
\text { Queensland }\end{array}$ & terepi kísérlet & 8 (gyom) \\
\hline $\begin{array}{l}\text { ANSONG \& } \\
\text { PICKERING } 2016\end{array}$ & Ausztrália & $\begin{array}{l}\text { Gold Coast Campus, } \\
\text { Queensland }\end{array}$ & kísérleti vizsgálat & 33 (gyepi és gyom) \\
\hline $\begin{array}{l}\text { AUFFRET \& } \\
\text { COUSINS } 2013\end{array}$ & Svédország & $\begin{array}{l}\text { természetközeli } \\
\text { gyepek és legelők }\end{array}$ & terepi kísérlet & 197 (gyepi) \\
\hline HUISKES et al. 2014 & Antarktisz & Antarktisz & kérdőíves felmérés & gyom \\
\hline $\begin{array}{l}\text { LEFCORT \& } \\
\text { LEFCORT } 2014\end{array}$ & $\begin{array}{c}\text { ÉNy } \\
\text { Amerika }\end{array}$ & Préri & kísérleti vizsgálat & 1 (inváziós) \\
\hline KuLBABA et al. 2009 & Kanada & rurál élőhelyek & kísérleti vizsgálat & $\begin{array}{l}8 \text { (gyepi és } \\
\text { inváziós) }\end{array}$ \\
\hline $\begin{array}{l}\text { MoUnT \& } \\
\text { PICKERING } 2009\end{array}$ & Ausztrália & $\begin{array}{l}\text { Kosciuszko Nemzeti } \\
\text { Park }\end{array}$ & terepi kísérlet & 70 (gyepi és gyom) \\
\hline PICKERING et al. 2011 & Ausztrália & $\begin{array}{l}\text { Kosciuszko Nemzeti } \\
\text { Park }\end{array}$ & terepi kísérlet & 5 (gyepi és gyom) \\
\hline ScotT et al. 2009 & Ausztrália & ausztrál szavanna & terepi kísérlet & 1 (gyom) \\
\hline VIBRANS 1999 & $\begin{array}{c}\text { Dél- } \\
\text { Amerika }\end{array}$ & kukoricás & $\begin{array}{l}\text { terepi kísérlet és } \\
\text { kérdőíves felmérés }\end{array}$ & $\begin{array}{l}137 \text { (gyepi és } \\
\text { gyom) }\end{array}$ \\
\hline
\end{tabular}




\section{A vizsgálatok módszerei}

A tanulmányunkban bemutatott kutatások számos módszert alkalmaztak, hogy minél több ismeretet szerezzenek a ruházaton terjedő magok terjedési távolságáról és a ruházatra történő tapadásukról. Vizsgálták a magok tapadási sikerét adott útszakasz bejárása során (PICKERING et al. 2011, ANSONG \& PiCKERING 2013a, ANSONG \& PiCKERING 2015), tesztelték, hogy adott területen mennyi mag tapad a ruházatra (AUFFRET \& Cousins 2013), végeztek kérdőíves felméréseket, hogy megtudják, mi történik azokkal a propagulumokkal, amelyek a ruhákra tapadnak (VIBRANS 1999, ANSONG \& PICKERING 2013b, HuISKES et al. 2014), tesztelték a magok életképességét mosógépi mosást követően (LEFCORT \& LEFCORT 2014), valamint a diaspórák tapadási sikerét különböző intenzitású rázás esetében, rázógép használatával (ANSONG \& PICKERING 2016).

Milyen fajok és milyen mértékben képesek ruháinkon terjedni?

PICKERING \& MounT (2010) átfogó felmérést végeztek a véletlenszerű ember általi magterjesztésről. Pontos képet szerettek volna kapni arról, hogy mely fajok magjai terjedhetnek ruházattal. Összesen 57 családba tartozó 449 faj ruházaton való terjedéséről találtak publikált adatot. A fajok fele (55\%) mindössze öt családba tartozott. 127 faj a pázsitfűfélék (Poaceae), 70 faj a fészekvirágzatúak (Asteraceae), 30 faj a palkafélék (Cyperaceae), 26 faj a pillangósvirágzatúak (Fabaceae) és 23 faj a szegfüfélék (Caryophyllaceae) családjába tartozott. Az összegyüjtött fajok 87\%-a gyomnövényként ismert az egész világon. Az 1. Függelékben azokat a fajokat gyüjtöttük össze, amelyek Magyarországon is előfordulnak és van publikált adat a ruhán való terjedésükről. PICKERING \& MOUNT (2010) alapján a 262 Magyarországon is előforduló faj közül 41 gyom, 3 inváziós, 66 pedig zavarástűrő faj (2. táblázat, BoRHIDI 1995 besorolása alapján).

2. táblázat. PICKERING \& MOUNT (2010) fajlistája alapján a ruházattal terjedő, Magyarországon előforduló fajok száma, valamint ezek szociális magatartás típusa (BoRHIDI 1995 nyomán)

Table 2. Number of species and their social behaviour types (after BoRHIDI 1995) that occur in Hungary and have been recorded to be dispersed by clothing (PICKERING \& MOUNT 2010)

$\mathrm{AC}=$ tájidegen agresszív kompetítorok / alien competitors; $\mathrm{RC}$ = honos flóra ruderális kompetítorai / ruderal competitors; $\mathrm{A}=$ behurcolt gyomok / adventives; $\mathrm{I}=$ kivadult haszonnövények / introduced alien species; $\mathrm{W}$ = honos gyomfajok / weeds; DT = zavarástűrő fajok / disturbance tolerants; NP = természetes pionírok / natural pioneers; $\mathrm{G}$ = generalista stressz-tűrők / generalists; $\mathrm{Gu}$ = unikális generalisták / unique generalists; $\mathrm{C}$ = természetes kompetítorok / competitors; $\mathrm{Cu}=$ unikális természetes kompetítorok / unique competitors; $\mathrm{S}$ = specialista stressz-tűrők / specialists; $\mathrm{Sr}$ = ritka specialisták / rare specialists; Su = unikális specialisták / unique specialists; NA = hiányzó adat / not available

\begin{tabular}{|c|c|c|c|c|c|c|c|c|c|c|c|c|c|c|c|}
\hline \multirow{2}{*}{ Összesen } & \multicolumn{10}{|c|}{ A fajok szociális magatartás típusa } \\
\cline { 2 - 19 } & AC & RC & A & I & W & DT & NP & Gu & G & C & Cu & S & Sr & Su & NA \\
\hline 262 & 3 & 9 & 7 & 7 & 41 & 66 & 9 & 1 & 62 & 25 & 1 & 15 & 3 & 3 & 10 \\
\hline
\end{tabular}

KuLBABA et al. (2009) vizsgálatában nyolc növényfaj (Anemone canadensis, Arctium minus, Bidens frondosa, Geum aleppicum, Glycyrrhiza lepidota, Lappula echinata, Sanicula marilandica és Xanthium strumarium) magjának a tapadását vizsgálták öt emlősfaj (Peromyscus maniculatus, Procyon lotor, Odocoileus virginianus, Ursus americanus és Bison bison) szőrzetén, valamint a ruházat (pamut nadrág) esetében. A vizsgált öt emlősfaj közül az amerikai bölény (Bison bison) szőrzete bizonyult a legjobb magterjesztőnek, mivel a vizsgálatba bevont fajok magjai több, mint 50\%-os tapadást mutattak rajta. A két Kanadában inváziós növényfaj (Arctium minus és Lappula echinata) magjai több mint 50\%-os tapadást mutattak a pamut nadrágon, valamint a mosómedve (Procyon lotor) és az amerikai bölény (Bison bison) szőrén. A 
vizsgálat alapján mind a ruházatra mind az állatok szőrzetére tapadó magok fontos szerepet játszhatnak az őshonos és inváziós fajok kolonizációjában.

MOUNT \& PICKERING (2010) eredményei rávilágítanak arra a tényre, hogy a ruházat nagyon fontos szerepet játszik az ember általi magterjesztésben, de a magok és termések morfológiája is döntő fontosságú. Azon növényfajok, amelyek propagulumai hosszú szőrökkel, horgokkal, vagy egyéb tapadást elősegítő terjedő képlettel rendelkeznek, hatékonyabban terjedhetnek a ruházattal (AUFFRET \& CouSins 2013). Számos kutatás megerősítette, hogy az emberek a világ bármely pontjáról képesek magokat terjeszteni egyik élőhelyről a másikra. Éppen ezért ez a magterjesztés típus globális problémát jelent az egész világon, mivel a legtöbb esetben a gyomnövények, vagy az inváziós növények magjai terjednek (ANDERSON et al. 2015). Különösen fenyegetettek azok a régiók, amelyek elszigeteltségükből adódóan sérülékenyebbek az új behatásokkal szemben. E területekre került magok életképesek maradnak és kicsírázhatnak, így fokozatosan kiszoríthatják a ritka, védett és endemikus növényeket a területekről.

MOUNT \& PICKERING (2009) egy három kísérletből álló komplex vizsgálatot végeztek az ausztrál Kosciuszko Nemzeti Parkban. Kíváncsiak voltak, hogy milyen fajok diaspórái tapadhatnak az emberi ruházatra és befolyásolják-e a különböző típusú anyagok, valamint az eltérő ruhadarabok a tapadást. Az első vizsgálat során összehasonlították az útszélről és a természetes vegetációból a ruhákra tapadt magvakat és azt találták, hogy a két élőhelyről közel ugyanannyi diaspórát gyűjtöttek össze, viszont több gyomnövény magja került elő az útszélről, mint a természetes vegetációból. A második kísérletet tíz önkéntes bevonásával végezték, melynek során öt személy sport zoknit, a másik öt személy, pedig gyapjú zoknit viselt a kísérlet ideje alatt. A felmérésből kiderült, hogy a sport zoknira (pamut/nylon) hatékonyabban tapadtak a magok, mint a gyapjú/nylon zokni esetében. A harmadik kísérletnél egy személyen alkalmaztak egyszerre két kezelést, mégpedig úgy, hogy az egyik lábán lábszárvédőt kellett viselnie, míg a másik lába szabadon (csupasz) maradt. A vizsgálatot a park kijelölt útszakaszán hajtották végre, majd minden ruhadarabot óvatosan külön zsákokban összegyűjtöttek. Az utolsó vizsgálat eredményei alapján jelentősen csökkent a magok tapadási esélye a lábszárvédő viselése esetén. Összességében tehát elmondható, hogy az ember számos faj magját képes egyik élőhelyről a másikra terjeszteni. A vizsgálat során összesen 24776 magot gyűjtöttek össze, amely 70 különböző taxonhoz tartozott, ezek közül pedig 50-et azonosítottak faji szinten. Ezek között 31 gyom és 19 inváziós növény volt. Azon ruhadarabok viselése, amelyek nem teszik lehetővé a magvak tapadását (pl. lábszárvédő, hosszú nadrág, csizma), csökkenthetik a gyomés inváziós fajok új élőhelyekre történő terjesztését.

SCOTT et al. (2009) egyetlen faj, az Andropogon gayanus magjainak ember általi terjedését vizsgálták ausztráliai szavannás területeken. Az egyre nagyobb teret hódító gyomfaj magjainak ruházatra való tapadását négy kutató tesztelte. A felmérés során minden kutató ugyanolyan öltözetet viselt (hosszú nadrág, hosszú felső és hátizsák), majd a vizsgálat végén megszámolták a ruházatukra tapadt magokat. A felmérésből az derült ki, hogy a magok több mint 60\%-a a hátizsákok zsebeiben, a csizmában és a zoknikban gyült össze. Ezért nagyon fontos, hogy az emberek odafigyeljenek, hogy a kiemelten értékes természetvédelmi területek látogatásakor ruházatukon minél kevesebb zseb legyen, valamint a cipőt és zoknit teljesen lefedő nadrágot, lábszárvédőt viseljenek egy-egy túra alkalmával, megelőzve a nem kívánatos fajok terjedését.

AUFFRET \& Cousins (2013) vizsgálatukba olyan gazdákat vontak be, akik természetközeli gyepekben dolgoznak. Kíváncsiak voltak, hogy milyen magtulajdonságok vesznek részt a ruházatukra való tapadásban. A gazdák, akik a felmérésben részt vettek, a nap végén összegyüjtötték a magokat, amiket a ruhájukon találtak. Az eredményeik alapján olyan fajok magjai maradtak fenn a ruházaton, amelyek rendelkeztek a tapadáshoz szükséges morfológiai jellegekkel (horgokkal, szőrökkel, pappuszokkal stb.). Az állatokhoz hasonlóan az emberek is terjeszthetik bizonyos fajok magjait a tájban, azonban az emberiség világszerte növekvő mobilitása 
miatt az emberek magterjesztő szerepe eltolódott. A helyi és vidéki akciórádiusz egyre inkább a regionális mobilitás felé tolódik, ami leginkább az inváziós növények terjedésének kedvez.

A ruhákon terjedő magok sorsa

PICKERING et al. (2011) egy kísérleti vizsgálatot terveztek négy Európából származó, Ausztráliában gyomnövényként számon tartott faj (Anthoxanthum odoratum, Dactylis glomerata, Festuca rubra és Rumex acetosa) és egy Ausztráliában őshonos faj (Acaena novae-zelandiae) magjainak a bevonásával. Kétféle ruhadarabon (zokni és nadrág) tesztelték a magok tapadását egy rövid $(150 \mathrm{~m})$ és egy hosszú $(5000 \mathrm{~m})$ séta után. Jelentős különbségeket találtak a fajok között és a különböző anyagú ruhadarabokra tapadt magok közti arányban. Kiderült, hogy a vizsgált öt faj szorosabban tapadt a zoknihoz (pamut/nylon), mint a nadrághoz (vászon/pamut) még az 5000 m-es séta után is, különösen az Acaena és az Anthoxanthum fajok esetében. Az 5000 m-es séta után az Acaena magok 25\%-kal, az Anthoxanthum pedig 34\%-kal nagyobb valószínűséggel maradtak a zoknin, mint a rövid séta után a nadrágon. A másik három faj esetében már a séta kezdetén a magok több mint a fele leesett, míg a hosszú séta után már csak néhány mag (8-16\%) maradt a nadrágon és a zoknin.

ANSONG \& PICKERING (2013b) kérdőíves felmérést végeztek, hogy megtudják az ausztráliai D’Aguilar Nemzeti Parkot látogatók mit tesznek a ruhájukra tapadt magokkal. A megkérdezettek 63\%-a talált a ruháján magokat, melyeket a legtöbben leszedtek és a park területén szórtak szét, néhányan pedig otthon a ruhákkal együtt kimosták őket. Mivel Ausztráliában az inváziós fajok elleni védekezéssel kapcsolatos tájékoztatásra igen nagy hangsúlyt fordítanak, a megkérdezettek egy része külön figyelmet fordított a megtapadt magok további sorsára, és néhányan elkülönítve tárolták zacskókban az összegyűjtött magokat. A magvak ruházattal történő terjedésében fontos szerepet játszik az emberi viselkedés, ezért a fokozottan védett területeket látogatók megfelelő tájékoztatása az ember általi magterjesztésről hasznos lehet, hogy megelőzzük az inváziós- és gyomnövények további terjedését.

ViBRANS (1999) vizsgálatában a dél-közép Mexikóban található Puebla és Tlaxcala régiók kukoricásainak flóráját vizsgálta. Kíváncsi volt, hogy ezeken a területeken előforduló fajok számára milyen vektorok biztosítják a hosszútávú terjedést, hiszen a magas kukoricásban a nagytestü állatoknak nincs bejárása, a madarak is többnyire nem ezeket a területeket választják költési területnek. Az előforduló fajok magmorfológiájuk alapján, illetve figyelembe véve az élőhely szerkezetét, a széllel mint hosszútávú terjesztő vektorral nem képesek hatékonyan terjedni. Az epizoochor magterjedés szerepe szintén minimálisra csökken a magas kukoricásban, mivel kizárólag kisemlősök által valósulhat meg. Azonban az epizoochoriához alkalmazkodott növények magassága $(>80 \mathrm{~cm})$, szintén csökkenti a kisemlősök szőrzetén keresztüli terjedés esélyét. Ezért a legvalószínűbb terjesztő vektorok az emberek lehetnek. Ezt a következtetést erősítette meg a gazdákkal készített interjú (45 gazda), amelyből kiderült, hogy a vegetációs időszakban sok időt töltenek a területen és számos növényfaj magját találták a ruházatukon. A kukoricásban előforduló gyomnövények számára az ember általi magterjesztés biztosíthatja a terjedést és a fennmaradást.

A Kakadu Nemzeti Parkban ANSONG \& PICKERING (2013a) vizsgálatában a gyomnövények magjait a hasonló magmorfológiájú őshonos Heteropogon contortus füfaj magjaival helyettesítették és megvizsgálták, milyen távolságra terjedhetnek a magok a zoknira és a nadrágra tapadva. A résztvevők ugyanolyan zoknit (pamut/nylon) és nadrágot (vászon/pamut) viseltek a felmérés során. Az 5 km-es út bejárása alatt folyamatosan feljegyezték a zoknin és a nadrágon rajtamaradt magokat. Az eredményekből kiderült, hogy a diaspórák 55\%-a az 5 km-es séta után is a ruházaton maradhat, így az ember akarata ellenére hosszú távon is terjesztheti a hasonló morfológiával rendelkező gyomok magjait is. 
Egy későbbi vizsgálatukban ANSONG \& PICKERING (2015) korábban begyüjtött nyolc gyomnövény magjait helyezték fel nadrágokra és zoknikra. Ezután 5 km-es sétát tettek a Gold Coast Campus területén, ahol folyamatosan figyelték a diaspórákat. Az eredmények alapján a tapadási idő változó, amit sok tényező befolyásol, mint például a ruházat típusa és a magok morfológiája. Ugyancsak ANSONG \& PICKERING (2016) vizsgálata során 33 faj magjait gyüjtötték be útmenti és zavart területekről. A magokat két csoportra osztották: horgokkal, szőrökkel rendelkezőkre és az ezekkel nem rendelkezőkre. Rövid és hosszú sétákat szimuláltak rázógép segítségével. A magokat különböző ruhadarabokra helyezték (pamut nadrág, pamut zokni és gyapjú dzseki), ezután pedig a rázógépbe helyezték, ahol a rövid séta 5 perc, a hosszú séta 50 perces rázást jelentett. Az eredményekből az derült ki, hogy 18 faj alacsony tapadással rendelkezett, 10 faj közepes és csak 5 fajnak volt magas tapadási értéke, amelyek a rázást követően is fennmaradtak a ruhákon. A tapadás mértékét a ruhadarabok típusa nagymértékben befolyásolhatja, mivel a bolyhos felületű ruhákon tovább rajta tudnak maradni a magok, mint a sima felületű ruhákon. Az eredmények alapján a magok tapadása függ a különböző szövetekből készült ruházat típusától, valamint a magok morfológiájától. Ennek a ténynek a tudatosítása, valamint a megfelelő ruhadarabok kiválasztása lényegesen csökkentené a magok terjedését egy-egy túra során.

HUISKES et al. (2014) vizsgálatuk során arra voltak kíváncsiak, hogy az Antarktiszra érkező emberek ruházatán milyen arányban találhatóak meg magvak, mohák és zuzmók. A kontinensre látogatóknak kérdőívet kellett kitölteniük, hogy néhány előzetes információt szolgáltassanak a kutatók számára (például honnan érkeztek, milyen célból jöttek a kontinensre, hol tartózkodtak közvetlen az utazás előtt). Eredményeik alapján az Antarktiszra látogatók közül a legtöbb propagulumot a kutatók terjeszthetik, hiszen ők azok, akik számos élőhelytípust bejárnak és ezáltal potenciális terjesztőkké válhatnak. A vizsgálatból kiderült, hogy a legtöbb magot, mohát és zuzmót az emberek a cipőjükön, a nadrágon és a táskákon terjesztik. Ez a vizsgálat arra világít rá, hogy fontos tényezőként szerepel az emberi magterjesztésben az előzetes tartózkodási hely, hiszen akár az Antarktiszig is képes az ember a magokat szállítani.

LEFCORT \& LEFCORT (2014) vizsgálatában a Bromus tectorum magok életképességét vizsgálta mosógépi mosást követően. A következő kezeléseket alkalmazta: az első csoport magjait mosószerrel mosták ki, a második csoporthoz a mosószeren kívül fehérítőt is hozzáadtak és úgy mosták ki a magokat, végül pedig a kontroll csoport, amin semmilyen kezelést nem alkalmaztak. Az eredmények alapján a Bromus tectorum csírázására nem volt negatív hatással egyik kezelés sem, viszont a mosás és fehérítő hatása csökkentette a növény növekedését.

A fent bemutatott vizsgálatok eredményei alapján elmondható, hogy az ember képes, akár nagyon távoli területekre is diaspórákat szállítani. Sajnos a legtöbb esetben az ember ruháján gyomnövények, vagy inváziós fajok magjai terjednek, amelyek súlyos természetvédelmi károkat okoznak a legtöbb régióban. Ezért különösen fontos lenne, hogy az emberek odafigyeljenek a ruházatuk ellenőrzésére és a megfelelő öltözet kiválasztására, hogy csökkenteni tudják a nem kívánatos fajok magjainak terjesztését a területek között.

\section{Következtetések}

Az áttekintett tanulmányok alapján az emberi ruházat a magok terjedésének fontos helyszíne, azonban egyelőre nagyon kevés a témakörben végzett vizsgálat. A téma azért különösen jelentős, mert az ember egyre nagyobb távolságokat tesz meg, egyre többféle élőhely között teremt meg biológiai kapcsolatot. Olyan élőhelyekből vihet magokat új területekre, amelyek között emberi közvetítés nélkül aligha valósulna meg az érintkezés. Az Antarktiszra már számos növényfaj jutott el emberi segítséggel, és a klímaváltozás hatására közülük egyre több találhat a megtelepedéshez megfelelő feltételeket (HuISKES et al. 2014). Az elszigetelt területekre (pl. szi- 
getek) szállított propagulumok száma egyre növekszik a mobilitással. Ugyanakkor fontos kiemelni, hogy az emberek egy-egy túra után urbanizált területekre térnek vissza, ahová szintén terjeszthetik a magokat. A városok klímája világszerte hasonló, valamint a városi élőhelyek hasonló környezeti feltételekkel rendelkeznek a világ számos pontján (DEÁK et al. 2016b, HüsE et al. 2016). Ennek következtében az eltérő régiókból származó fajok magjai számára jó megtelepedést biztosíthatnak a városi élőhelyek és akár inváziók kiindulópontjai is lehetnek. A téma jelentősége pont az emberi mobilitás növekedésében, kiszámíthatatlanságában van.

A magoknak a ruházaton keresztüli hatékony terjedéséhez nagyon sok szempontnak kell teljesülnie. Többnyire a szőrökkel, horgokkal, pappuszokkal, vagy egyéb, a tapadást elősegítő képletekkel rendelkező diaspórák a legsikeresebbek a ruházaton való megtapadásban. Ez a típusú adaptáció lehetővé teszi, hogy az eddigi vektorokon kívül egy további vektor, vagyis az ember is eredményes legyen a magok terjesztésében (AUFFRET \& Cousins 2013). A leghosszabb távon a pamut/nylon és a vászon/pamut anyagú, a legrövidebb ideig, pedig a vízlepergető (lábszárvédő, vagy kamásli) anyagú ruhákon képesek fennmaradni a propagulumok. A ruhatípusok és részeik közül a zokni és a zsebek azok, amik a leghosszabb ideig képesek őrizni a megtapadt magvakat. Ezért, ha redukálni tudjuk ezek mennyiségét saját ruházatunkon, akkor csökkenthetjük a terjesztett fajok magjainak a számát. Fontos figyelembe venni a ruházat típusát, mivel kiemelt hatást gyakorol a propagulumok tapadására. A sport zoknira (pamut/nylon) lazább szövésének köszönhetően sokkal több faj magja képes rátapadni, mint a túra zoknikra (gyapjú/nylon), amelyek textúrájukból adódóan sokkal simább felületet képeznek. Ennek oka, hogy a lazább szövésű anyagok réseiben a kisméretű, de tapadást segítő képletekkel nem rendelkező propagulumok is meg tudnak tapadni (ANSONG \& PICKERING 2016). A nadrág (vászon/pamut) viselése akár teljes mértékben (94\%-ban) képes csökkenteni a zoknira való tapadást. Ezért a gondosan megválasztott ruhadarabok viselése az egyik módja lehet annak, hogy csökkenteni tudjuk a ruházatunkra tapadt magok mennyiségét (MounT et al. 2009).

Azt, hogy az egyes fajok milyen messzire terjedhetnek, még kevés vizsgálat igazolta kísérletesen, de az eddigi kísérletek alapján $150 \mathrm{~m}$ és $5 \mathrm{~km}$ közötti a várható távolság abban az esetben, ha csak gyalogos közlekedést veszünk figyelembe (PICKERING et al. 2011, ANSONG \& PiCKERING 2013a, ANSONG \& PICKERING 2015). Ezek a távolságok a közlekedési eszközök használatával a sokszorosára nőhetnek, így a magok olyan elszigetelt területekre eljuthatnak, ami más módon nem volna lehetséges (pl. Antarktisz, Ausztrália, Új-Zéland) (MounT \& PICKERING 2009, HUISKES et al. 2014). Egyelőre úgy tűnik, hogy az ember ruházatán történő magterjesztésnek több negatív hatása bizonyított, mint pozitív. Ezért további kutatásokra van szükség, hogy megoldásokat találjunk ezekre a problémákra, különösen azokban a régiókban, ahol korlátozott a kutatások száma ebben a témakörben, mint Európa, Dél-Amerika, Ázsia és Afrika.

Az eddigi tapasztalatok alapján a tudatos elővigyázatosság a legcélravezetőbb megoldás a nem kívánatos gyom- és inváziós növények terjesztésének megfékezésére. Ennek megvalósítása érdekében nélkülözhetetlen feladat az emberek megfelelő tájékoztatása.

\section{Köszönetnyilvánítás}

A szerzőket az NKFI FK 124404 (LK, VO) és az NKFI-ERC-M-127070 (VO) pályázat, valamint a Bolyai János Kutatási Ösztöndíj (VO) támogatta. Köszönet Fekete Réka és Lovas-Kiss Ádám alapos bírálatáért és hasznos tanácsaiért. 


\section{Irodalomjegyzék}

Anderson L.G., Rocliffe S., Haddaway N.R. \& Dunn A.M. (2015): The role of tourism and recreation in the spread of non-native species: a systematic review and meta-analysis. - PloS ONE 10 (10): e0140833.

ANSONG M. \& PiCKERING C. (2013a): Long-distance dispersal of Black Spear Grass (Heteropogon contortus) seed on socks and trouser legs by walkers in Kakadu National Park. - Ecological Management \& Restoration 14 (1): 71-74.

Ansong M. \& Pickering C. (2013b): Weed hygiene: what do we do with seeds we find on our clothing? 19th Australiasian Weeds Conference. Science, Community and Food Security: the weed Challenge. Hobart, Tazmania.

Ansong M. \& Pickering C. (2014): Weed seeds on clothing: A global review. - Journal of Environmental Management 144: 203-211.

ANSONG M., PiCKERING C. \& ARTHUR J.M. (2015): Modelling seed retention curves for eight weed species on clothing. - Austral Ecology 40 (7): 765-774.

Ansong M. \& Pickering C. (2016): The effects of seed traits and fabric type on the retention of seed on different types of clothing. - Basic and Applied Ecology 17 (6): 516-526.

Auffret A.G. (2011): Can seed dispersal by human activity play a useful role for the conservation of European grasslands? - Applied Vegetation Science 14 (3): 291-303.

AufFRET A.G. \& Cousins S.A. (2013): Humans as long-distance dispersers of rural plant communities. - PloS ONE 8 (5): e62763.

BoRHIDi A. (1995): Social behaviour types, the naturalness and relative indicator values of the higher plants in the Hungarian Flora - Acta Botanica Hungarica 39: 97-181.

DEÁK B., VALKó O., TöRÖK P. \& TóTHMÉRÉSZ B. (2016a): Factors threatening grassland specialist plants - A multi-proxy study on the vegetation of isolated grasslands. - Biological Conservation 204: 255-262.

DEÁK B., HÜSE B. \& TóTHMÉRÉSZ B. (2016b): Grassland vegetation in urban habitats - Testing ecological theories. - Tuexenia 36: 379-393.

Hardiman N., Dietz K.C., Bride I. \& Passfield L. (2017): Pilot testing of a sampling methodology for assessing seed attachment propensity and transport rate in a soil matrix carried on boot soles and bike tires. - Environmental Management 59 (1): 68-76.

Hughes K.A., LEe J.E., WARE C., KIEFER K. \& BERGSTROM D.M. (2010): Impact of anthropogenic transportation to Antarctica on alien seed viability. - Polar Biology 33 (8): 1125-1130.

Huiskes A.H., Gremmen N.J., Bergstrom D.M., Frenot Y., Hughes K.A., ImURA S. ... \& WARE C. (2014): Aliens in Antarctica: assessing transfer of plant propagules by human visitors to reduce invasion risk. Biological Conservation 171: 278-284.

HüSE B., SZABó SZ., DEÁK B. \& TóthmÉRÉSz B. (2016): Mapping ecological network of green habitat patches and their role in maintaining urban biodiversity in and around Debrecen city (Eastern Hungary). Land Use Policy 57: 574-581.

Kulbaba M.W., TARDiF J.C. \& StAniforth R.J. (2009): Morphological and ecological relationships between burrs and furs. - The American Midland Naturalist 161 (2): 380-391.

LEFCORT H. \& LEFCORT C. (2014): Cheatgrass (Bromus tectorum) seeds are still viable after laundry cycle. Natural Areas Journal 34 (4): 505-508.

Levin S.A., Muller-Landau H.C., NAthan R. \& Chave J. (2003): The ecology and evolution of seed dispersal: a theoretical perspective. - Annual Review of Ecology, Evolution, and Systematics 34 (1): 575-604.

Lovas-Kiss Á., Sonkoly J., Vincze O., Green A.J., TaKÁcs A. \& Molnár V.A. (2015): Strong potential for endozoochory by waterfowl in a rare, ephemeral wetland plant species, Astragalus contortuplicatus (Fabaceae). - Acta Societatis Botanicorum Poloniae 84 (3): 321-326.

LovAs-Kiss Á., Vizi B., VincZE O., MolnáR V.A. \& GREEN A.J. (2018): Endozoochory of aquatic ferns and angiosperms by mallards in Central Europe. - Journal of Ecology 106 (4): 1714-1723.

MounT A. \& PickERING C.M. (2009): Testing the capacity of clothing to act as a vector for non-native seed in protected areas. - Journal of Environmental Management 91 (1): 168-179.

NATHAN R. (2006): Long-distance dispersal of plants. - Science 313 (5788): 786-788.

Niggemann M., JetZkowitz J., BRunZel S., Wichmann M.C. \& BialozYT R. (2009): Distribution patterns of plants explained by human movement behavior. - Ecological Modelling 220 (9-10): 1339-1346. 
PiCKERING C. \& MounT A. (2010): Do tourists disperse weed seed? A global review of unintentional humanmediated terrestrial seed dispersal on clothing, vehicles and horses. - Journal of Sustainable Tourism 18 (2): 239-256.

Pickering C.M., MounT A., Wichmann M.C. \& Bullock J.M. (2011): Estimating human-mediated dispersal of seeds within an Australian protected area. - Biological Invasions 13 (8): 1869-1880.

ScoTT K.A. (2009): Potential for the dispersal of weed seeds on clothing: an example with Gamba Grass in northern Australia. - Ecological Management \& Restoration 10 (1): 71-73.

TAYLOR K., BRUMMER T., TAPER M.L., WING A. \& REW L.J. (2012): Human-mediated long-distance dispersal: an empirical evaluation of seed dispersal by vehicles. - Diversity and Distributions 18 (9): 942-951.

VAN DER PIJL L. (1982): Principles of dispersal. - Berlin: Springer-Verlag.

VIBRANS H. (1999): Epianthropochory in Mexican weed communities. - American Journal of Botany 86 (4): 476-481.

Vitousek P.M., D'Antonio C.M., Loope L.L., RejMAnek M., \& Westbrooks R. (1997): Introduced species: a significant component of human-caused global change. - New Zealand Journal of Ecology 21: 1-16.

Wichmann M.C., Alexander M.J., Soons M.B., Galsworthy S., Dunne L., Gould R., Fairfax C., Niggemann M., HAILS R.S. \& BULLOCK J.M. (2009): Human-mediated dispersal of seeds over long distances. Proceedings of the Royal Society of London B: Biological Sciences 276 (1656): 523-532.

Beérkezett / received: 2018. 03. 20. • Elfogadva / accepted: 2018. 07. 02. 
LUKÁCS K \& VALKó 0. (2018):

A ruházat szerepe az ember általi magterjesztésben / The role of clothing in antropochorous seed dispersal

Kitaibelia 23 (1): 77-86.

DOI: 10.17542/kit.23.77

\section{Elektronikus melléklet / Electronic appendix}

1. Függelék. Az eddigi ruházaton történő magterjesztést vizsgáló tanulmányokban talált, és Magyarországon előforduló fajok listája PICKERING \& MounT (2010) áttekintő cikke alapján. A fajok után tájékoztató jelleggel megadtuk azok szociális magatartás típusát BoRHIDI (1995) alapján. A rövidítések magyarázata a 2. táblázatban található.

\begin{tabular}{|c|c|c|c|}
\hline Fajlista & $\begin{array}{c}\text { Szociális } \\
\text { Magatartás Típus } \\
\end{array}$ & Fajlista & $\begin{array}{c}\text { Szociális } \\
\text { Magatartás Típus } \\
\end{array}$ \\
\hline Acetosella vulgaris & DT & Bromus sterilis & $\mathrm{RC}$ \\
\hline Achillea millefolium & DT & Bromus tectorum & DT \\
\hline Achillea pannonica & DT & Calamagrostis canescens & $\mathrm{C}$ \\
\hline Aegopodium podagraria & $\mathrm{C}$ & Calamagrostis pseudophragmites & G \\
\hline Agrimonia eupatoria & DT & Calamagrostis purpurea & NA \\
\hline Agrostis capillaris & $\mathrm{C}$ & Calamagrostis stricta & $\mathrm{Cu}$ \\
\hline Agrostis stolonifera & $\mathrm{C}$ & Callitriche stagnalis & NA \\
\hline Aira caryophyllea & NP & Calluna vulgaris & $\mathrm{S}$ \\
\hline Aira elegantissima & NP & Campanula patula & G \\
\hline Alnus glutinosa & $\mathrm{C}$ & Campanula persicifolia & G \\
\hline Alopecurus pratensis & $\mathrm{C}$ & Campanula rapunculoides & DT \\
\hline Anagallis arvensis & $\mathrm{W}$ & Campanula rotundifolia & $\mathrm{G}$ \\
\hline Anemone hepatica & S & Capsella bursa-pastoris & W \\
\hline Anemone nemorosa & S & Cardamine pratensis & $\mathrm{G}$ \\
\hline Anethum graveolens & I & Carex acuta & G \\
\hline Angelica sylvestris & G & Carex acutiformis & $\mathrm{C}$ \\
\hline Anthoxanthum odoratum & $\mathrm{C}$ & Carex canescens & $\mathrm{Sr}$ \\
\hline Anthriscus sylvestris & DT & Carex diandra & $\mathrm{S}$ \\
\hline Aquilegia vulgaris & $\mathrm{Sr}$ & Carex divulsa & DT \\
\hline Arabidopsis thaliana & DT & Carex echinata & $\mathrm{S}$ \\
\hline Arabis hirsuta & $\mathrm{G}$ & Carex flava & S \\
\hline Arctium majus (Arctium lappa) & $\mathrm{W}$ & Carex nigra & $\mathrm{G}$ \\
\hline Arctium minus & $\mathrm{W}$ & Carex pallescens & DT \\
\hline Arenaria serpyllifolia & NP & Carex panicea & $\mathrm{G}$ \\
\hline Arrhenatherum elatius & DT & Carex pilulifera & $\mathrm{Sr}$ \\
\hline Artemisia campestris & G & Carex remota & $\mathrm{C}$ \\
\hline Artemisia vulgaris & $\mathrm{W}$ & Carex spicata & DT \\
\hline Asperugo procumbens & $\mathrm{W}$ & Carex sylvatica & $\mathrm{G}$ \\
\hline Asperula tinctoria & G & Carex vulpina & DT \\
\hline Astragalus glycyphyllos & G & Centaurea cyanus & W \\
\hline Atriplex patula & $\mathrm{W}$ & Centaurea jacea & G \\
\hline Atriplex prostrata & $\mathrm{W}$ & Centaurea rhenana & G \\
\hline Avena barbata & NA & Centaurea scabiosa & G \\
\hline Avena fatua & W & Centaurium erythraea & G \\
\hline Avena sterilis & NA & Cerastium brachypetalum & NP \\
\hline Bellis perennis & DT & Cerastium glomeratum & G \\
\hline Berteroa incana & $\mathrm{W}$ & Cerastium vulgare & DT \\
\hline Betula pendula & $\mathrm{C}$ & Chamerion angustifolium & DT \\
\hline Betula pubescens & $\mathrm{Su}$ & Chelidonium majus & W \\
\hline Brassica napus & $\mathrm{A}$ & Chenopodium album & $\mathrm{RC}$ \\
\hline Brassica nigra & A & Circaea lutetiana & $\mathrm{G}$ \\
\hline Brassica oleracea & I & Cirsium arvense & $\mathrm{RC}$ \\
\hline Briza media & G & Cirsium oleraceum & $\mathrm{G}$ \\
\hline Bromus inermis & $\mathrm{C}$ & Cirsium palustre & $\mathrm{G}$ \\
\hline Bromus madritensis & NA & Convolvulus arvensis & $\mathrm{RC}$ \\
\hline Bromus molliformis & DT & Conyza canadensis & A \\
\hline Bromus racemosus & DT & Crataegus monogyna & G \\
\hline
\end{tabular}




\begin{tabular}{|c|c|c|c|}
\hline Fajlista & $\begin{array}{c}\text { Szociális } \\
\text { Magatartás Típus } \\
\end{array}$ & Fajlista & $\begin{array}{c}\text { Szociális } \\
\text { Magatartás Típus } \\
\end{array}$ \\
\hline Crepis biennis & DT & Lathyrus pratensis & DT \\
\hline Crepis capillaris & NP & Leontodon autumnalis & DT \\
\hline Crepis paludosa & $\mathrm{S}$ & Lepidium campestre & DT \\
\hline Cynodon dactylon & $\mathrm{RC}$ & Leucanthemum vulgare & $\mathrm{G}$ \\
\hline Cynosurus cristatus & $\mathrm{C}$ & Linum catharticum & G \\
\hline Cynosurus echinatus & A & Linum usitatissimum & I \\
\hline Cyperus difformis & A & Lolium multiflorum & W \\
\hline Dactylis glomerata & DT & Lolium perenne & DT \\
\hline Daucus carota & DT & Lotus corniculatus & DT \\
\hline Deschampsia cespitosa & $\mathrm{C}$ & Lychnis flos-cuculi & $\mathrm{G}$ \\
\hline Dianthus carthusianorum & $\mathrm{G}$ & Malus sylvestris & $\mathrm{G}$ \\
\hline Dianthus deltoides & DT & Matricaria maritima subsp. inodora & $\mathrm{W}$ \\
\hline Digitalis purpurea & $\mathrm{I}$ & Matricaria recutita & $\mathrm{G}$ \\
\hline Digitaria ciliaris & NA & Medicago lupulina & DT \\
\hline Digitaria sanguinalis & $\mathrm{AC}$ & Medicago sativa & I \\
\hline Echinochloa colona & $\mathrm{AC}$ & Melampyrum arvense & DT \\
\hline Echinochloa crus-galli & $\mathrm{AC}$ & Melampyrum pratense & $\mathrm{G}$ \\
\hline Echium vulgare & W & Melica nutans & $\mathrm{G}$ \\
\hline Eleusine indica & I & Melilotus albus & W \\
\hline Elytrigia repens & $\mathrm{RC}$ & Milium effusum & $\mathrm{G}$ \\
\hline Fallopia convolvulus & $\mathrm{W}$ & Molinia caerulea & NA \\
\hline Festuca arundinacea & DT & Montia fontana & $\mathrm{S}$ \\
\hline Festuca gigantea & $\mathrm{G}$ & Mycelis muralis & G \\
\hline Festuca heterophylla & $\mathrm{C}$ & Nepeta cataria & W \\
\hline Festuca nigrescens & $\mathrm{C}$ & Oxalis corniculata & $\mathrm{AC}$ \\
\hline Festuca ovina & $\mathrm{S}$ & Papaver dubium & $\mathrm{W}$ \\
\hline Festuca pratensis & $\mathrm{C}$ & Pastinaca sativa & DT \\
\hline Festuca rubra & $\mathrm{C}$ & Persicaria lapathifolia & $\mathrm{W}$ \\
\hline Filipendula ulmaria & $\mathrm{G}$ & Persicaria maculosa & W \\
\hline Filipendula vulgaris & $\mathrm{G}$ & Phalaroides arundinacea & $\mathrm{G}$ \\
\hline Fraxinus excelsior & $\mathrm{C}$ & Phleum pratense & G \\
\hline Galium album & G & Phragmites australis & $\mathrm{C}$ \\
\hline Galium aparine & W & Pimpinella saxifraga & G \\
\hline Galium boreale & $\mathrm{G}$ & Pinus sylvestris & $\mathrm{C}$ \\
\hline Galium mollugo & $\mathrm{G}$ & Plantago lanceolata & DT \\
\hline Galium palustre & $\mathrm{G}$ & Plantago major & $\mathrm{W}$ \\
\hline Galium spurium & $\mathrm{W}$ & Plantago media & DT \\
\hline Galium tricornutum & $\mathrm{W}$ & Poa annua & $\mathrm{RC}$ \\
\hline Galium uliginosum & $S$ & Poa nemoralis & $\mathrm{C}$ \\
\hline Galium verum & DT & Poa pratensis & $\mathrm{G}$ \\
\hline Genista tinctoria & $\mathrm{G}$ & Poa trivialis & DT \\
\hline Geranium robertianum & DT & Polygala vulgaris & $\mathrm{G}$ \\
\hline Geranium sylvaticum & $\mathrm{Su}$ & Polygonum aviculare & $\mathrm{RC}$ \\
\hline Geum urbanum & DT & Potentilla erecta & DT \\
\hline Glechoma hederacea & DT & Primula veris & $\mathrm{G}$ \\
\hline Glyceria fluitans & $\mathrm{C}$ & Prunella vulgaris & DT \\
\hline Gnaphalium uliginosum & DT & Prunus spinosa & $\mathrm{C}$ \\
\hline Helianthemum ovatum & $\mathrm{G}$ & Ranunculus acris & $\mathrm{G}$ \\
\hline Helictotrichon pubescens & $\mathrm{G}$ & Ranunculus arvensis & $\mathrm{W}$ \\
\hline Heracleum mantegazzianum & NA & Ranunculus repens & DT \\
\hline Holcus lanatus & $\mathrm{G}$ & Rhinanthus minor & $\mathrm{G}$ \\
\hline Holcus mollis & $\mathrm{G}$ & Rhinanthus serotinus & NA \\
\hline Hordeum marinum & A & Rubus idaeus & DT \\
\hline Hordeum vulgare & NA & Rumex acetosa & DT \\
\hline Hypericum maculatum & $\mathrm{G}$ & Rumex conglomeratus & W \\
\hline Hypericum perforatum & DT & Rumex crispus & W \\
\hline Hypochaeris radicata & $\mathrm{A}$ & Rumex maritimus & $\mathrm{W}$ \\
\hline Jasione montana & $\mathrm{S}$ & Sagina nodosa & $\mathrm{S}$ \\
\hline Juncus articulatus & DT & Sagina procumbens & DT \\
\hline Juncus bufonius & DT & Saxifraga granulata & $\mathrm{Gu}$ \\
\hline Juncus effusus & DT & Scabiosa ochroleuca & DT \\
\hline Knautia arvensis & DT & Scleranthus annuus & W \\
\hline Lapsana communis & DT & Scorzonera humilis & $\mathrm{S}$ \\
\hline Lathyrus linifolius & $\mathrm{Su}$ & Secale cereale & $\mathrm{NA}$ \\
\hline
\end{tabular}




\begin{tabular}{|c|c|c|c|}
\hline Fajlista & $\begin{array}{c}\text { Szociális } \\
\text { Magatartás Típus } \\
\end{array}$ & Fajlista & $\begin{array}{c}\text { Szociális } \\
\text { Magatartás Típus } \\
\end{array}$ \\
\hline Senecio jacobaea & DT & Tribulus terrestris & NP \\
\hline Seseli annuum & G & Trifolium arvense & DT \\
\hline Setaria pumila & W & Trifolium campestre & DT \\
\hline Setaria verticillata & W & Trifolium dubium & G \\
\hline Silene nutans & $\mathrm{G}$ & Trifolium montanum & G \\
\hline Silene vulgaris & DT & Trifolium pratense & DT \\
\hline Sisymbrium officinale & W & Trifolium repens & DT \\
\hline Solanum nigrum & W & Tripleurospermum maritimum & NA \\
\hline Sonchus arvensis & W & Trisetum flavescens & $\mathrm{S}$ \\
\hline Sonchus asper & $\mathrm{W}$ & Triticum aestivum & NA \\
\hline Sonchus oleraceus & W & Urtica dioica & DT \\
\hline Sonchus palustris & DT & Vaccinium myrtillus & $\mathrm{S}$ \\
\hline Spergula arvensis & W & Valeriana officinalis & G \\
\hline Stellaria graminea & DT & Verbascum thapsus & $\mathrm{W}$ \\
\hline Stellaria media & DT & Veronica arvensis & DT \\
\hline Succisa pratensis & G & Veronica austriaca & $G$ \\
\hline Tanacetum vulgare & W & Veronica chamaedrys & DT \\
\hline Taraxacum officinale & $\mathrm{RC}$ & Veronica persica & W \\
\hline Thymus serpyllum & $\mathrm{C}$ & Vicia cracca & DT \\
\hline Torilis arvensis & $\mathrm{W}$ & Viola arvensis & W \\
\hline Torilis japonica & DT & Vulpia bromoides & NP \\
\hline
\end{tabular}

